\title{
PENGEMBANGAN MASYARAKAT ISLAM MELALUI PERAN LEMBAGA PUSAT KEGIATAN BELAJAR MASYARAKAT (PKBM) BINA MANDIRI CIPAGERAN (Studi Kasus di PKBM Bina Mandiri Cipageran Kota Cimahi)
}

\author{
Nugraha Permana Putra \\ Dosen Jurusan Pendidikan Guru Sekolah Dasar Fakultas Keguruan Ilmu Pendidikan \\ Universitas Muhammadiyah Cirebon \\ nugrahapermana1990@gmail.com
}

\begin{abstract}
ABSTRAK
Penelitian ini bertujuan untuk mengetahui: 1) Untuk mendeskripsikan partisipasi tokoh masyarakat dalam perencanaan pengembangan masyarakat Islam melalui program kesetaraan paket B di PKBM Bina Mandiri Cipageran. 2) Untuk mendeskripsikan peran lembaga PKBM dalam pelaksanaan pengembangan masyarakat Islam melalui program kesetaraan paket B di PKBM Bina Mandiri Cipageran. 3) Untuk mendeskripsikan peran PKBM dalam meningkatkan kualitas pengembangan masyarakat Islam melalui program paket B di PKBM Bina Mandiri Cipageran. Penelitian ini merupakan penelitian deskriptif dengan pendekatan kualitatif. Subyek penelitian ini adalah peran PKBM, tutor dan warga belajar yang terlibat dalam program pengembangan masyarakat Islam di PKBM Bina Mandiri Cipageran. Pengumpulan data dilakukan dengan menggunakan metode observasi, wawancara, dan dokumentasi. Peneliti merupakan instrumen utama dalam melakukan penelitian, yang dibantu oleh pertanyaan penelitian, pedoman wawancara, dan dokumentasi. Teknik yang digunakan dalam analisis data adalah reduksi data, display data dan pengambilan simpulan. Trianggulasi yang dilakukan untuk menjelaskan keabsahan data dengan menggunakan trianggulasi sumber dan metode. Hasil penelitian menunjukkan bahwa: 1) Peran pengelola dalam pelaksanaan program pengembangan masyarakat Islam melalui program kesetaraan paket B di PKBM Bina Mandiri sebagai pemrakarsa, pengelola, tutor, motivator dan penyedia fasilitas belajar. 2) Peran PKBM sebagai pemrakarsa memiliki gagasan dan melakukan rapat bersama pengelola untuk merencanakan program pengembangan masyarakat Islam.
\end{abstract}

Kata Kunci: Peran PKBM, Warga Belajar, Pengembangan Masyarakat Islam

\begin{abstract}
This study aims to find out: 1) To describe the participation of community leaders in planning the development of Islamic society through the package B equality program in PKBM Bina Mandiri Cipageran. 2) To describe the role of PKBM institutions in the implementation of Islamic community development through the package $B$ equality program in PKBM Bina Mandiri Cipageran. 3) To describe the role of PKBM in improving the quality of Islamic community development through the B package program at PKBM Bina Mandiri Cipageran. This research is a descriptive study with a qualitative approach. The subject of this research is the role of PKBM, tutors and learning citizens involved in the Islamic community development program at PKBM Bina Mandiri Cipageran. Data collection is done by using the method of observation, interviews, and documentation. Researchers are the main instrument in conducting research, which is assisted by research questions, interview guidelines, and documentation. The techniques
\end{abstract}


used in data analysis are data reduction, data display and conclusion taking. Triangulation was carried out to explain the validity of the data by using source triangulation and methods. The results of the study show that: 1) The role of the manager in the implementation of the Islamic community development program through the $B$ package equality program in PKBM Bina Mandiri as the initiator, manager, tutor, motivator and learning facilities provider. 2) The role of PKBM as the initiator has ideas and holds meetings with managers to plan Islamic community development programs.

Keywords: The Role of PKBM, Citizens Learning, Islamic Community Development 


\section{PENDAHULUAN}

Dikalangan masyarakat Indonesia akhir-akhir ini, istilah pendidikan mendapatkan arti yang sangat luas, hal ini terjadi karena kata-kata pendidikan, pengajaran, bimbingan dan pelatihan, sebagai istilah-istilah teknis tidak lagi dibeda-bedakan oleh masyarakat kita, tetapi ketiga-tiganya lebur menjadi satu pengertian baru tentang pendidikan.

Pendidikan adalah suatu aktivitas untuk mengembangkan seluruh aspek kepribadian manusia yang berjalan seumur hidup. Dengan kata lain pendidikan tidak hanya berlangsung di dalam kelas, tetapi pula di luar kelas Pendidikan bukan bersifat formal saja, tetapi mencakup pula yang non formal.

Dalam realitanya, selain terdapat pendidikan formal juga terdapat pendidikan nonformal yang diselenggarakan bagi warga masyarakat yang memerlukan layanan pendidikan yang berfungsi sebagai pengganti, penambah, dan/atau pelengkap pendidikan formal dalam rangka mendukung pendidikan sepanjang hayat.

Salah satu pendidikan nonformal adalah pendidikan kesetaraan, misalnya sekolah kejar paket B yang setara dengan pendidikan tingkat SLTP. Program Kejar Paket B ini dapat kita kategorikan dalam jenis pendidikan non formal. Sebagaimana disebutkan dalam UU RI No. 20 Tahun 2003 tentang Sistem Pendidikan Nasional
(SISDIKNAS) Bagian kelima pasal 26 ayat 3 bahwa: "Pendidikan non formal meliputi pendidikan kecakapan hidup, pendidikan anak usia dini, pendidikan kepemudaan, pendidikan pemberdayaan perempuan, pendidikan keaksaraan, pendidikan ketrampilan dan pelatihan kerja, pendidikan kesetaraan, serta pendidikan lain yang ditujukan untuk mengembangkan kemampuan peserta didik". Sejak pemerintah mencanangkan wajib belajar pendidikan dasar 9 tahun, program Pendidikan Luar Sekolah seperti Kejar Paket B setara SLTP mendapat respons yang positif berupa tingginya minat dan jumlah warga masyarakat yang mengikuti Paket B setara SLTP.

Pendidikan, baik itu formal maupun nonformal tentu tidak dapat lepas dari kegiatan belajar mengajar dan membaca. Belajar dapat dijadikan sebagai suatu kegiatan untuk memperoleh pengetahuan dan keterampilan serta sikap yang diperlukan oleh setiap orang. Selain itu belajar juga dapat dilakukan untuk memperoleh jawaban dari suatu masalah. Belajar selalu melekat pada kehidupan, karena setiap orang selalu dihadapkan oleh persoalan-persoalan baru di dalam kehidupannya. Oleh karena itu, setiap orang dituntut untuk selalu meningkatkan kemampuannya untuk menganalisis dan memperbaiki cara-cara mempelajari sesuatu. 
Pusat Kegiatan Belajar Masyarakat (PKBM) merupakan bagian yang tidak terpisahkan dari keberadaan Pendidikan Nonformal di Indonesia. Pusat Kegiatan Belajar Masyarakat (PKBM) merupakan wadah yang dibentuk dari, oleh, dan untuk masyarakat dengan tujuan untuk meningkatkan pengetahuan, keterampilan, dan kemandirian warga belajar. Salah satu program di PKBM adalah pendidikan kesetaraan Paket B setara SLTP. Penyelenggaraan program belajar Paket B dalam pembelajaran dirancang dengan beberapa komponen, diantaranya tujuan pembelajaran, materi atau kurikulum pembelajaran, tutor atau pendidik, warga belajar, fasilitas atau sarana dan prasarana pembelajaran, dan waktu pembelajaran.

Untuk mengetahui bagaimana mengembangkan peran dan fungsi PKBM dalam memfasilitasi belajar masyarakat, perlu dilakukan eksplorasi secara mendalam. Sebagai pusat belajar di masyarakat, PKBM dapat dilihat sebagai serangkaian kegiatan belajar membelajarkan masyarakat yang dapat dilakukan di waktu yang berbeda. Teknologi pendidikan merupakan studi dan praktik etis dalam memfasilitasi belajar dan meningkatkan kinerja dengan menciptakan, menggunakan dan mengelola proses dan sumber teknologi yang tepat (Januszweski \& Molenda, 2008). Dengan menggunakan pendekatan teknologi pendidikan tersebut, maka untuk memfasilitasi masyarakat belajar sepanjang hayat dilihat dari tiga fungsi utama teknologi pendidikan, yaitu menciptakan (creating), menggunakan (using), serta mengelola (managing) proses dan sumber belajar dalam memfasilitasi serta meningkatkan kinerja masyarakat melalui PKBM. Penggunaan teknologi yang tepat dapat memecahkan masalah di PKBM dalam memfasilitasi belajar masyarakat dengan tepat pula.

Berdasarkan uraian latar belakang tersebut maka fokus penelitian ini adalah bagaimana pengembangan masyarakat Islam melalui peran lembaga Pusat Kegiatan Belajar Masyarakat (PKBM) pada program kesetaraan paket $B$ di PKBM Bina Mandiri Cipageran. Penelitian ini bertujuan untuk memberikan deskripsi mendalam serta memaknai bagaimana pengembangan masyarakat Islam melalui peran lembaga pusat kegiatan belajar masyarakat (PKBM) pada program kesetaraan paket B di PKBM Bina Mandiri Cipageran. Hasil penelitian ini diharapkan dapat memberikan gambaran mengenai pengalaman bagaimana pengembangan masyarakat Islam melalui peran lembaga pusat kegiatan belajar masyarakat (PKBM) pada program kesetaraan paket $B$ di PKBM Bina Mandiri Cipageran pengembangan masyarakat Islam melalui peran lembaga pusat kegiatan belajar masyarakat (PKBM) pada program kesetaraan paket B di PKBM Bina Mandiri Cipageran, baik secara teoretis maupun praktis.

\section{KAJIAN PUSTAKA}

\section{Pengembangan Masyarakat Islam}

Pengembangan masyarakat (community development) dalam bahasa Arab disebut dengan tathwirul mujtama' il-Islamiy adalah kegiatan pengembangan masyarakat yang 
dilakukan secara sistematis, terencana, dan diarahkan untuk memperbesar akses masyarakat guna mencapai kondisi sosial, ekonomi, dan kualitas kehidupan yang lebih baik apabila dibandingkan dengan kegiatan pembangunan Selain itu, pengertian pengembangan masyarakat terdapat beberapa definisi yang dikemukakan dalam sejumlah sumber antara lain: (a) Menurut Bhattacarya, pengembangan masyarakat adalah pengembangan manusia yang bertujuan untuk mengembangkan potensi dan kemampuan manusia untuk mengontrol lingkungannya. Pengembangan masyarakat merupakan usaha membantu manusia mengubah sikapnya terhadap masyarakat, membantu menumbuhkan kemampuan untuk berorganisasi, berkomunikasi dan menguasai lingkungan fisiknya. Manusia didorong untuk mampu membuat keputusan, mengambil inisiatif dan mampu berdiri sendiri. (b) Menurut Yayasan Indonesia Sejahtera, pengembangan masyarakat adalah usaha-usaha yang menyadarkan dan menanamkan pengertian kepada masyarakat agar dapat menggunakan dengan lebih baik semua kemampuan yang dimiliki, baik alam maupun tenaga, serta menggali inisiatif setempat untuk lebih banyak melakukan kegiatan investasi dalam mencapai kesejahteraan yang lebih baik (Anninymous, 2011: 48). (c) Menurut Com. Dev. Handbook, pengembangan masyarakat adalah evolusi terencana dari aspek ekonomi, sosial, lingkungan dan budaya yang ada dalam masyarakat. Dia adalah sebuah proses di mana anggota masyarakat melakukan aksi bersama dan menyelesaikan permasalahan yang dihadapi bersama. (d) Menurut Sudjana, pengembangan masyarakat mengandung arti sebagai upaya yang terencana dan sistematis yang dilakukan oleh, untuk dan dalam masyarakat guna meningkatkan kualitas hidup penduduk dalam semua aspek kehidupannya dalam suatu kesatuan wilayah (Suhu, 2005: 27).

Dakwah adalah upaya mengajak masyarakat menuju cara hidup Islami dalam segala aspek kehidupan, baik aspek kerohanian, maupun aspek sosial ekonomi, politik, budaya dan hukum yang ada di masyarakat, dakwah secara etimologi adalah bentuk mashdar dari kata kerja da'a-yad'u-da'watan atau du'aan yang berarti menyeru, mengajak, memanggil, mengadu, berdoa, memohon, menyuruh dan meminta (Sihotang, 2012:1). Dari seluruh makna dakwah tersebut terdapat makna komunikasi antara dai dengan mad'u. Komunikasi tersebut dapat berbentuk ceramah, bimbingan dan juga pengembangan masyarakat. Dalam alQuran term dakwah dalam berbagai bentuknya ditemukan sebanyak 299 kali (Fuad, 2006:144). Rasulullah SAW., selaku dai dan kepala negara Madinah telah berupaya mengembangkan masyarakat kaum muslimin menuju iman dan takwa demi kebahagiaan hidup dunia dan akhirat. Pengembangan masyarakat lebih tepat menggunakan 
bentuk da'wah bi al-hal karena lebih menekankan aspek pelaksanaan suatu program kegiatan daripada komunikasi lisan berbentuk ceramah. Ini berarti bahwa pengembangan masyarakat berkaitan erat dengan manajemen dakwah menyangkut perencanaan, organisasi, pelaksanaan dan evaluasi kegiatan pengembangan. Prinsip pembangunan masyarakat Islam adalah holistik dan mempedulikan semua aspek kehidupan, termasuk eksistensi komponen alam bukan manusia (non human society). Pengembangan dimaksudkan sebagai upaya merubah masyarakat tradisional, miskin, terbelakang dan tidak beriman menuju masyarakat modern yang maju, kreatif, beriman dan bertakwa.

\section{Ruang Lingkup Pengembangan Masyarakat Islam}

Konsep Pengembangan Masyarakat Islam pada hakikatnya semua pembangunan dilaksanakan untuk meningkatkan kesejahteraan masyarakat baik jasmani maupun rohani. Untuk itu pembangunan terhadap masyarakat desa dan kota dipusatkan pada mereka (people centered development) melalui suatu gerakan yang dinamakan pengembangan masyarakat (community development).

Definisi di atas pada hakikatnya memberikan gambaran tentang upaya untuk meningkatkan kemampuan masyarakat serta berusaha menciptakan suatu kondisi yang memancing kemauan dan inisiatif sendiri dari masyarakat yang bersangkutan. Dengan adanya peningkatan kemampuan dan inisiatif mereka, diharapkan masyarakat semakin mandiri dan mampu memahami permasalahan yang dihadapi serta potensi yang mereka miliki untuk dimanfaatkan semaksimal mungkin. Berdasarkan pemikiran tersebut di atas, Dunham menjelaskan bahwa pengembangan masyarakat mencakup: (a) Program terencana yang difokuskan pada seluruh kebutuhan masyarakat. (b) Bantuan teknis berbagai keahlian yang terintegrasi untuk membantu masyarakat. (c) Suatu penekanan utama atas self-help dan partisipasi oleh masyarakat.

Pengembangan masyarakat adalah suatu proses, baik ikhtiar masyarakat yang bersangkutan yang diambil berdasarkan prakarsa sendiri, maupun kegiatan pemerintah dalam rangka memperbaiki kondisi ekonomi, sosial dan kebudayaan berbagai komunitas, mengintegrasikan berbagai komunitas itu ke dalam kehidupan bangsa, dan memampukan mereka untuk memberikan sumbangan sepenuhnya demi kemajuan bangsa dan negara, berjalan secara terpadu di dalam proses tersebut. Proses tersebut meliputi dua elemen dasar yaitu partisipasi masyarakat itu sendiri dalam usaha mereka untuk memperbaiki taraf hidup mereka sedapat-dapatnya berdasarkan kekuatan dan prakarsa mereka sendiri; dan bantuan-bantuan teknis serta pelayanan lainnya yang dimaksud membangkitkan prakarsa, tekad untuk menolong diri sendiri dan kesediaan membantu orang lain serta membuat 
semua itu lebih efektif. Dengan demikian, adanya partisipasi aktif dan inisiatif masyarakat dalam pembangunan akan mampu memperbaiki kondisi masyarakat yang miskin dan terbelakang ke arah yang lebih baik. Sejalan dengan itu maka terdapat 6 (enam) dimensi yang menjadi perhatian dalam pelaksanaan pengembangan masyarakat (community development), yang saling terkait satu dengan lainnya. Kegagalan pada satu dimensi akan sangat berpengaruh terhadap dimensi yang lainnya. Adapun keenam dimensi tersebut mencakup dimensi sosial, ekonomi, politik, kebudayaan, lingkungan dan personal atau spiritual. Berpijak pada uraian mengenai beberapa tujuan pengembangan masyarakat yang telah disampaikan di atas, terdapat nilai-nilai yang menjadi orientasi dari pengembangan masyarakat. $\mathrm{Di}$ antara nilai-nilai tersebut yang pantas di kedepankan adalah nilai kebersamaan (musawah), demokrasi (syura) dan rasa percaya diri (yaqin) dengan cara mengembangkan potensi masyarakat. Salah satu ciri khas pengembangan masyarakat menurut Islam adalah aplikasi tauhid dalam setiap program pengembangan, mulai dari prencanaan (takhtihith), pengorganisasian (tanzhim), pelakasanaan kegiatan ('amaliyah) dan evaluasi.

\section{Definisi dan Jenis Program Pusat Kegiatan Belajar Masyarakat}

Beberapa ahli mendefiniskan Pendidikan Luar Sekolah dengan segala aspeknya. Berbagai definisi tersebut dimaksudkan sebagai upaya untuk menjelaskan batasan dan ciri-ciri pendidikan luar sekolah terutama dengan pendidikan persekolahan. Definisi Pendidikan Luar Sekolah menurut Coombs dalam Sudjana (2004: 22) adalah: Setiap kegiatan terorganisasi dan sistematis, di luar sistem persekolahan yang mapan, dilakukan secara mandiri atau merupakan bagian penting dari kegiatan yang lebih luas, yang sengaja dilakukan untuk melayani peserta didik tertentu di dalam mencapai tujuan belajarnya.

Selanjutnya Sudjana (2004:46) menjelaskan pengertian Pendidikan Luar Sekolah menurut The South East Asian Ministry of Education Organi-zation (SEAMO, 1971) sebagai berikut: Pendidikan Luar Sekolah adalah setiap upaya pendidikan dalam arti luas yang di dalamnya terdapat komunikasi yang teratur dan terarah, diselenggarakan di luar subsistem pendidikan formal, sehingga seseorang atau kelompok memperoleh informasi, latihan, dan bimbingan sesuai dengan tingkatan usia dan kebutuhan hidupnya.

Pembelajaran pada hakikatnya adalah proses interaksi antara peserta didik dengan lingkungannya, sehingga terjadi perubahan prilaku ke arah yang lebih baik. Uzer Usman (2008:94) mengemukakan bahwa proses belajar mengajar merupakan suatu proses yang mengandung serangkaian perbuatan guru dan siswa atas dasar hubungan timbal balik yang berlangsung dalam situasi edukatif untuk mencapai tujuan tertentu. 
Pendidikan kesetaraan merupakan pendidikan nonformal yang diselenggarakan oleh pendidikan luar sekolah, kesetaraan paket B atau setara SMP sudah di tentukan oleh UndangUndang No. 20/2003 Sistem pendidikan Nasional, pasal 26, ayat (6).

Guru atau pengajar merupakan unsur terpenting dalam menentukan sukses atau gagalnya pengajaran. Hakekat pekerjaan mengajar bukanlah sekadar melakukan sesuatu bagi si murid, tetapi lebih berupa menggerakkan murid melakukan hal-hal yang dimaksudkan menjadi tujuan pendidikan. Guru mendorong memberikan inspirasi, memberikan motif-motif dan membimbing murid dalam usaha mereka mencapai tujuan pendidikan.

Guru selalu berada dalam hubungan erat dengan murid. Ia berusaha untuk mengarahkan minat dan semangat belajar murid sehingga tercapai hasil yang memuaskan (Moh. Surya, 2005:127).

Pekerjaan sebagai guru adalah pekerjaan yang luhur dan mulia, baik ditinjau dari sudut masyarakat maupun sudut agama. Tinggi rendahnya, maju atau mundurnya kebudayaan suatu masyarakat dan negara, sebagian besar tergantung pada pendidikan dan pengajaran yang diberikan oleh guruguru (Ngalim Purwano, 2004:126).

Pendidikan kesetaraan meliputi program Kejar Paket A setara SD ( 6 tahun), Paket B setara SMP ( 3 tahun ), dan Paket C setara SMA ( 3 tahun ). Program ini semula ditujukan bagi peserta didik yang berasal dari masyarakat yang kurang beruntung, tidak pernah sekolah, putus sekolah dan putus lanjut, serta usia produktif yang ingin meningkatkan pengetahuan dan kecakapan hidup.

Di samping itu dimaksudkan juga untuk masyarakat lain yang memerlukan layanan khusus dalam memenuhi kebutuhan hidupnya sebagai dampak dari perubahan peningkatan taraf hidup, ilmu pengetahuan dan teknologi.

Tidak ada batasan usia dalam program kesetaraan ini. Pegawai Negeri, ABRI, anggota DPR, karyawan pabrik banyak yang memanfaatkan program kesetaraan ini untuk meningkatkan kualifikasi ijazah mereka.

Definisi mengenai setara adalah sepadan dalam civil effect, ukuran, pengaruh, fungsi dan kedudukan. Sebagaimana yang tercantum dalam Undang-Undang Nonomor 20 Tahun 2003 tentang Sistem Pendidikan Nasional, Pasal 26 Ayat (6) bahwa: "Hasil pendidikan nonformal dapat dihargai setara dengan hasil program pendidikan formal setelah melalui proses penilaian penyetaraan oleh lembaga yang ditunjuk oleh Pemerintah atau Pemerintah Daerah dengan mengacu pada standar nasional pendidikan".

Oleh karena itu pengertian pendidikan kesetaraan adalah jalur pendidikan nonformal dengan standar kompetensi lulusan yang sama dengan sekolah formal, tetapi kontens, konteks, metodologi, dan pendekatan untuk mencapai standar kompetensi lulusan tersebut lebih memberikan konsep terapan, tematik, induktif, yang terkait 
dengan permasalahan lingkungan dan melatihkan kecakapan hidup berorientasi kerja atau berusaha sendiri.

Dengan demikian pada standar kompetensi lulusan diberi catatan khusus. Catatan khusus ini meliputi: pemilikan keterampilan dasar untuk memenuhi kebutuhan sehari-hari (Paket A), pemilikan keterampilan untuk memenuhi tuntutan dunia kerja, dan pemilikan keterampilan berwirausaha (Paket C).

Perbedaan ini oleh kekhasan karateristik peserta didik yang karena berbagai hal tidak mengikuti jalur pendidikan formal karena memerlukan substansi praktikal yang relevan dengan kehidupan nyata.

Pusat Kegiatan Belajar Mengajar (PKBM) merupakan wadah yang dibentuk dari, oleh, dan untuk masyarakat dengan tujuan untuk meningkatkan pengetahuan, keterampilan, dengan memanfaatkan sarana, prasarana dan potensi yang ada di sekitar ling-kungannya. Penyelenggaraan pen-didikan baik formal maupun nonformal merupakan suatu sistem dan sekaligus suatu prosedur.

Sebagai suatu sistem, pada hakikatnya penyelenggaraan pendidikan merupakan suatu keseluruhan yang meliputi komponen-komponen masukan, proses, dan kelulusan. Komponen masukan meliputi unsur-unsur peserta didik, tenaga kependidikan, sumber material dan biaya, dan sumber informasi. Komponen proses meliputi unsur-unsur pembinaan kurikulum, strategi pembelajaran, media pembelajaran, pengajaran lapangan, praktek kerja dan pengabdian kepada masyarakat. Komponen produk meliputi jumlah dan mutu kelulusan, terutama kemampuan akademik dan/atau kemampuan profesional. Komponenkomponen dan unsur-unsur yang terkandung saling berhubungan, saling mempengaruhi, dan saling bergantung, serta saling menerobos satu dengan yang lainnya dalam rangka mencapai tujuan pendidikan tinggi, dalam hal ini adalah proses kegiatan belajar mengajar.

Upaya peningkatan minat belajar peserta didik difokuskan pada pelaksanaan proses belajar mengajar, dengan mengasumsikan bahwa untuk meningkatkan minat belajar, metode mengajar perlu diperbaiki dan lebih profesional. Hasil pembelajaran yang optimal dapat diperoleh bila pengelola pengajaran di sekolah dilakukan secara profesional, termasuk kemampuan para guru melakukan berbagai pendekatan yang variatif dalam mengajar sehingga peserta didik merasa tertarik dan terpanggil untuk lebih giat belajar khususnya membaca.

Pada dasarnya minat dan kebiasaan membaca merupakan keterampilan yang diperoleh seseorang dilahirkan dan bukan merupakan keterampilan bawaan, melainkan perlu dipupuk, dibina, dan dikembangkan. Minat dan kegemaran membaca tidak dengan sendirinya dimiliki seseorang. Minat baca dapat tumbuh dan berkembang dengan cara dibentuk.

Secara teoritis minat baca seseorang dapat diartikan sebagai 
kecenderungan hati yang tinggi orang tersebut kepada suatu sumber bacaan tertentu (Sutarno, 2006: 27).

Berdasarkan pengertian teori di atas maka minat baca seseorang merupakan ketertarikan seseorang terhadap sumber bacaan tertentu dan sebagai sikap positif dari adanya rasa keterikatan dalam diri terhadap aktivitas membaca. Aspek minat membaca meliputi perasaan senang terhadap buku bacaan, kesadaran akan manfaat membaca, frekuensi membaca, dan jumlah buku bacaan yang pernah dibaca (Sinambela dalam Rahayu, 2009: 16).

Dari beberapa uraian, definisi dan pendapat para ahli diatas maka dapat diklasifikasikan beberapa indikator untuk mengukur minat baca warga belajar sebagai berikut.

a. Perasaan dan emosi

Suatu perhatian yang kuat dan mendalam disertai dengan perasaan senang terhadap kegiatan membaca sehingga mengarahkan seseorang untuk membaca dengan keamauannya sendiri.

b. Kesadaran akan manfaat membaca Warga belajar sadar akan manfaat dari membaca di antaranya menambah ilmu dan wawasan.

c. Usaha yang dilakukan

Warga belajar mencari bahan bacaan yaitu dengan cara membeli atau meminjam bahan bacaan dari taman bacaan masyarakat (TBM) atau perpustakaan.

d. Frekuensi membaca

Waktu yang dibutuhkan warga belajar untuk menyelesaikan bahan bacaan serta frekuensi membaca bahan bacaan.

\section{Prinsip Pengembangan Program PKBM}

Beberapa prinsip dasar yang dapat dijadikan acuan dalam pengembangan dan menyusun program PKBM antara lain adalah:

a. Program yang dikembangkan PKBM harus meluas sehingga warga belajar memperoleh kesempatan yang luas untuk mengembangkan pengalaman tentang pengetahuan, keterampilan, sikap dan nilai yang berkaitan dengan etika, estetika, logika dan kinestetika pada saat pembelajaran.

b. Program harus memiliki prinsip keseimbangan (balanced) di mana setiap kompetensi yang dikembangkan dalam program PKBM harus dicapai melalui alokasi waktu yang cukup untuk sebuah proses pembelajaran yang efektif, c) pro-gram yang dikembangkan PKBM harus relevan karena setiap program terkait dengan penyiapan warga belajar untuk meningkatkan mutu kehidupan melalui kesempatan, pe-ngalaman, dan latihan dalam berperan dan bersikap secara bertanggung jawab dalam mewujudkan kedewasaan berpikirnya, d) program yang dikembangkan PKBM harus mampu mengedepankan konsep perbedaan (differentiated), prinsip ini merupakan upaya pelayanan individual di mana warga belajar harus memahami: apa yang perlu dipelajari; bagaimana berpikir, 
bagaimana belajar, dan berbuat untuk me-ngembangkan potensi dan kebutuhan dirinya masing-masing secara optimal.

Untuk mendukung terlaksananya prinsip-prinsip tersebut, maka ada beberapa hal yang perlu menjadi patokan pengembang PKBM meliputi: a) kualitas sumberdaya manusia yang mengusung program, b) kemampuan bekerja sama dengan pihak-pihak tertentu (masyarakat, pemerintah, dan sumber-sumber lainnya),

c) kemampuan (kualitas, kompetensi) sumber belajar (tutor, fasilitator) terutama kesesuaian dengan program, d) warga belajar yang berminat dan butuh dengan program yang dikembangkan, e) fasilitas pendukung program yang representatif sesuai dengan kebutuhan program, f) partisipasi masyarakat dalam pengembangan program, g) alat kontrol (supervisi monitoring, dan evaluasi) program, h) daya dukung lain seperti model yang akan dikembangkan, materi, modul, atau sumber lain yang sesuai dengan kebutuhan pembelajaran dan sasaran didik, i) anggaran untuk mendukung program, j) pemeliharaan program agar program tetap eksis, k) pengembangan program ke depan.

Sedangkan Sihombing dan Gutama (2000), menjelaskan bahwa beberapa faktor penunjang keberhasilan pengembangan program PKBM meliputi:

a) kemampuan mengidentifikasi dan mencatat kebutuhan masyarakat (warga belajar), b) melayani kebutuhan dan minat warga belajar dalam kegiatan yang bervariasi atau sesuai kebutuhan dan minatnya, c) memobilisasi sumberdaya yang ada di masyarakat, d) membangun kemitraan dan kerjasama secara terbuka secara terbuka dengan berbagai lembaga atau oranisasi, sehingga PKBM mampu mengembangkan berbagai aktivitas pembangunan masyarakat yang sesuai dengan kebutuhan lokal, e) memonitor perkembangan kegiatan serta keberhasilan sehingga dijadikan dasar pengembangan program ke depan, f) mencatat berbagai kelebihan dan kekurangan dari kegiatan yang dikelembagaan PKBM.

Langkah-langkah dalam penyusunan program PKBM dapat diikuti sebagai berikut: a) merencanakan program kegiatan, b) menentukan dan menetapkan berbagai sumber yang dibutuhkan baik sumber daya manusia, material maupun finansial, c) melakukan sosialisasi program ke masyarakat dan pemerintah daerah, d) menerima warga belajar, e) mencari kebutuhan warga belajar berkaitan dengan materi yang dikembangkan dalam program, f) menetapkan kebutuhan materi pembelajaran (program), g) menetapkan target dan tujuan program, h) menyusun kurikulum dan materi pembelajaran, i) menjalankan program, j) melakukan monitoring dan evaluasi program, k) mengembangkan program berdasarkan pada hasil monitoring dan evaluasi. Bidang pendidikan merupakan program andalan PKBM saat ini. Beberapa program pendidikan yang dikembangkan di antaranya adalah:

a. Program keaksaraan fungsional

Tujuan dari program ini adalah untuk meningkatkan keaksaraan dasar warga masyarakat yang masih buta aksara. Saat ini di Indonesia terdapat 
5,2 juta orang usia 10 sampai 44 tahun yang masih buta huruf, apabila ditambah dengan anak yang putus sekolah (drop out) maka jumlah tersebut akan mencapai 6 juta orang (Depdiknas, 2006). Olah karena itu sasaran dari kegiatan ini adalah melayani warga masyarakat yang menyandang buta aksara berusia di antara 10 sampai 44 tahun, dengan prioritas usia antara 17 sampai 30 tahun. Materi pembelajaran dan bahan atau sarana pembelajaran dikembangkan sesuai dengan kebutuhan dan mata pencaharian warga belajar. Perkembangan kemampuan dan keterampilan warga belajar dicatat oleh tutor sebagai hasil evaluasi pembelajaran, terutama berhubungan dengan mata pencahariannya, baik dalam bentuk tulisan maupun perubahan tingkah laku warga belajar selama mengikuti (proses) pembelajaran. Sangat dimungkinkan tidak ada tes khusus hasil belajar.

b. Pengembangan anak dini usia (early childhood)

Salah satu program yang dikembangkan di PKBM adalah program pendidikan anak usia dini. Alasan dasar mengapa program ini dikembangkan karena sampai saat ini perhatian terhadap pendidikan anak usia dini masih sangat rendah. Padahal, konsep pembangunan Sumber Daya Manusia (SDM) justru dimulai sejak masa usia dini. Rendahnya kualitas hasil pendidikan di Indonesia selama ini cerminan rendahnya kualitas SDM Indonesia. Oleh sebab itu PKBM memiliki kewajiban untuk mengembangkan program tersebut sejalan dengan tujuan dan fungsi PKBM di tengah-tengah masyarakat.

c. Program kesetaraan (equivalency education)

Rendahnya kualitas sumber daya manusia Indonesia salah satunya diakibatkan oleh tingginya angka putus sekolah, pada level pendidikan dasar dan level pendidikan menengah. Pada tingkat Sekolah Dasar 25 persen dari jumlah lulusannya tidak melanjutkan ke jenjang (level) yang lebih tinggi atau jenjang SMP/Mts, begitu pula 50 persen lulusan SMP/Mts tidak melanjutkan ke jenjang SMA/MA. (Depdiknas 2006). Oleh karena permasalahan-permasalahan tersebut, program kesetaraan merupakan program yang sangat vital dalam menjawab permasalahan kualitas (mutu) sumber daya manusia. Sesuai dengan fungsi dan peranannya PKBM sebagai pusat kegiatan pembelajaran masyarakat memiliki peran penting dalam mengembangkan programprogram kesetaraan di tengah-tengah masyarakatnya. Program kesetaraan melingkupi program Kelompok Belajar paket A setara SD/MI, Kelompok Belajar Paket B setara SMP/MTs dan Kelompok Belajar Paket C SMA/MA.

d. Kelompok belajar usaha

Program kelompok belajar usaha (KBU) diperuntukkan bagi masyarakat (warga belajar) yang minimal telah bebas buta aksara dan atau selesai program kesetaraan. Juga masyarakat lainnya yang merasa perlu untuk 
meningkatkan dan memperoleh pengetahu-an serta keterampilan baru. Warga belajar dikelompok belajar usaha dapat memilih berbagai alternatif jenis keterampilan dan jenis usaha yang akan dikembangkan dalam kelompoknya sesuai dengan kebutuhan dan minatnya.

e. Pengembangan program magang pada PKBM

Salah satu program yang teridentifikasi dikembangkan PKBM adalah program magang. Dalam PKBM magang dibagi dalam dua kegiatan ada magang individual dan ada magang kelompok. Magang individual adalah magang yang dilakukan oleh satu orang warga belajar pada kegiatan-kegiatan pelatihan atau keterampilan tertentu. Sedangkan magang kelompok adalah pemagangnya lebih dari 1 orang biasanya 2 sampai dengan 5 orang. Jenis keterampilan yang dimagangkan sangat bervariasi dan tergantung kebutuhan dan kesiapan warga belajar serta kesiapan PKBM dalam meyiapkan program-program yang sesuai dengan dunia industri. Sasaran magang adalah warga belajar yang minimal sudah terbebas dari buta huruf atau telah menyelesaikan pendidikan dasar (Paket A dan B, SD/MI, SMP/MTs) serta memiliki dasar keterampilan tertentu.

Program magang merupakan program khusus yang dikembangkan PKBM, dan tidak semua PKBM menyelenggarakan program ini karena menuntut kesiapan dan kerjasama dengan mitra (industri) atau bengkel kerja tertentu. Kegiatan magang yang diselenggarakan PKBM umumnya disesuaikan dengan daerah tertentu, seperti Bali, banyak warga belajar yang magang di galeri (lukisan), perhotelan atau menjadi guide (pengantar), serta magang pada industri kerajinan khas Bali seperti souvenir. Begitu pula di daerah lainnya seperti di Jawa Barat di daerah Tasikmalaya dan Ciamis magang banyak dilakukan pada industri pakaian khususnya border. Di Jawa Tengah magang keterampilan banyak dilakukan di industri batik baik yang berskala kecil maupun menengah.

f. Kursus keterampilan

Beberapa jenis keterampilan yang teridentifikasi dan dikembangkan dalam PKBM adalah: keterampilan komputer (software dan hardware), kursus keterampilan bahasa (Inggris, tata busana, Mandarin, Arab dan lainlain). Kursus mekanik otomotif, elektronika, perhotelan, tata busana, tata boga, tata kecantikan, gunting rambut, akupuntur, memasak, pijat dan lain-lain. Program-program tersebut dikembangkan untuk meningkatkan pengetahuan dan keterampilan dalam rangka mendukung profesi (profesional).

Program-program

PKBM dikembangkan secara bervariasi dan tergantung pada kebutuhan sasaran didik atau warga belajar. Jarang sekali ditemukan satu PKBM yang mengembangkan lebih dari 4 program kegiatan, paling dominan 2 sampai 3 program kegiatan dengan sasaran yang 
bervariasi, baik dari usia maupun latar belakang pendidikan dan ekonomi. Beberapa PKBM lebih banyak mengembangkan program yang sesuai dengan program pemerintah khususnya Direktorat Jendral Pendidikan Luar Sekolah atau program daerah seperti dari Dinas Pendidikan (Sub Dinas PLS).

Beragam satuan pendidikan nonformal yang terdapat pada PKBM harus menghadapi berbagai hambatan terkait dengan kinerja program-program yang dijalankan di dalamnya. Berbagai hambatan pendidikan masyarakat, menurut Sihombing (2001) dapat digambarkan sebagai berikut:

1. Perkembangan program belum diimbangi jumlah dan mutu yang memadai. Misalnya, penilik Dikmas masih ada beberapa yang menangani lebih dari satu kecamatan. Begitu pula dengan kebutuhan akan tutor, sebagai contoh untuk paket B setara SLTP, seharusnya membutuhkan rata-rata delapan orang tutor, kenyataannya baru dapat dipenuhi lima orang tutor untuk setiap kelompok belajar.

2. Rasio modul untuk warga belajar program kesetaraan yang masih jauh dari mencukupi. Rasio modul baru mencapai $1: 3$. Hal ini terjadi arena pengadaan modul murni dari pemerintah.

3. Tidak ada tempat belajar yang pasti. Hal ini menyebabkan adanya kesukaran pemantauan kebenaran pelaksanaan program pembelajaran.

4. Kualitas hasil belajar sulit dilihat kebenarannya dan sukar diukur tingkat keberhasilannya. Secara teoritis memang terdapat pembelajaran, tetapi dalam pelaksanaannya sulit dipertanggung jawabkan.

5. Lemahnya akurasi data tentang sasaran program. Kondisi ini disebabkan terbatasnya tenaga di lapangan baik secara kuantitas maupun kualitas serta sarana pendukung yang belum memadai.

6. Jadwal pelaksanaan belajar mengajar yang tidak selalu dilaksanakan tepat waktu.

\section{Tugas Pokok dan Fungsi PKBM}

Penyelenggaraan pendidikan berbasis masyarakat dalam bentuk PKBM merupakan arah baru dalam sistem pendidikan luar sekolah yang memiliki visi untuk memberdayakan masyarakat agar mampu meningkatkan kualitas hidupnya. "PKBM adalah suatu wadah dari berbagai kegiatan pem-belajaran masyarakat yang diarahkan pada pemberdayaan potensi untuk menggerakkan pembangunan di bidang sosial, ekonomi dan budaya". (Balai Pengembangan Kegiatan Belajar, 2001). PKBM dibentuk oleh masyarakat, merupakan milik masyarakat, dan dikelola oleh masyarakat yang pembentukannya dilakukan dengan memperhatikan sumber-sumber potensi yang terdapat pada daerah yang bersangkutan terutama jumlah kelompok sasaran dan jenis usaha/keterampilan yang secara ekonomi, sosial dan budaya dapat dikembangkan untuk meningkatkan kesejahteraan warga belajar khususnya dan warga masyarakat sekitarnya. Secara umum pembentukan PKBM bertujuan untuk memperluas 
kesempatan masyarakat khususnya yang tidak mampu untuk meningkatkan pengetahuan, keterampilan, dan sikap mental yang diperlukan untuk mengembangkan diri dan bekerja mencari nafkah. Sejalan dengan visi pembentukan PKBM tersebut maka tugas pokok PKBM adalah memberikan kemudahan bagi masyarakat khususnya masyarakat kurang mampu untuk mengembangkan diri melalui penyelenggaraan pendidikan luar sekolah dalam suatu wadah terpusat yang berasal dari, oleh dan untuk masyarakat dan diharapkan dapat tumbuh dan berkembang atas prakarsa masyarakat sendiri, sehingga akan lebih berorientasi pada kebutuhan belajar masyarakat setempat yang pada akhirnya mampu menjadikan PKBM sebagaisuatu wadah pembelajaran berkelanjutan. Sebagai tempat pembelajaran dan tempat sumber informasi bagi masyarakat yang dibentuk dan dikelola oleh masyarakat PKBM memiliki banyak fungsi, dalam hal ini Dinas Pendidikan Propinsi Jawa Barat (2002) menentukan lima fungsi PKBM, yaitu:

a. Sebagai tempat kegiatan belajar bagi warga masyarakat.

b. Sebagai tempat pusaran berbagai potensi yang ada dan berkembang di masyarakat.

c. Sebagai sumber informasi yang handal bagi warga masyarakat yang membutuhkan keterampilan fungsional.

d. Sebagai yang tukar-menukar berbagai pengetahuan dan keterampilan fungsional di antara warga masyarakat.

e. Sebagai tempat berkumpulnya warga masyarakat yang ingin meningkatkan pengetahuan dan keterampilannya.

Sementara Balai Pengembangan Kegiatan Belajar (2001) menentukan bahwa PKBM memiliki dua fungsi yaitu fungsi utama dan fungsi pendukung. Adapun fungsi utama PKBM menurut Balai Pengembangan Kegiatan Belajar (2001) adalah "Sebagai wadah berbagai kegiatan belajar masyarakat untuk meningkatkan pengetahuan, keterampilan, dan sikap yang diperlukan untuk mengembangkan diri dan masyarakat". Sedangkan Fungsi Pendukungnya adalah:

1. Sebagai pusat informasi bagi masyarakat sekitar, lembaga pemerintah dan lembaga swadaya masyarakat.

2. Pusat jaringan informasi dan kerjasama bagi lembaga yang ada di masyarakat (lokal) dan lembaga di luar masyarakat.

3. Sebagai tempat koordinasi, konsultasi, komunikasi dan bermusyawarah para pembina teknis, tokoh masyarakat dan para pemuka agama untuk merencanakan pembangunan dan pemberdayaan masyarakat desa.

4. Sebagai tempat kegiatan penyebarluasan program dan teknologi tepat guna.

5. Proses Manajemen PKBM

Berlakunya UU No. 22 Tahun 1999 tentang Pemerintahan Daerah serta UU No. 25 Tahun 1999 tentang Perimbangan 
Keuangan Pusat dan Daerah menuntut penanganan berbagai masalah, yang selama ini menjadi wewenang pemerintah pusat, termasuk masalah pendidikan yang selama ini ditangani secara sentralistik diserahkan kepada pemerintah kabupaten dan kota. Adanya perubahan tersebut menuntut perubahan di dalam manajemen pendidikan secara keseluruhan. Sehingga pemerintah kabupaten atau kota mempunyai wewenang penuh untuk mengelola pendidikan secara mandiri dengan memberdayakan semua potensi yang ada di daerah. Dengan adanya perubahan manajemen pendidikan ini diharapkan akan lebih meningkatkan kualitas pendidikan sebagaimana yang diharapkan. PKBM merupakan unit organisasi tersendiri dengan tata kerja dan personil yang terlibat di dalamnya. Sebagai suatu organisasi pendidikan mengemban tugas dan tanggungjawab berat karena bertugas mencetak sumber daya manusia handal yang memiliki keterampilan, kemampuan intelektual serta moralitas yang tinggi. Untuk itu, PKBM harus ditata dalam suatu sistem yang rapi melalui apa yang disebut manajemen PKBM.

Manajemen pendidikan tidak bisa disamakan dengan manajemen perusahaan atau bisnis karena pendidikan merupakan organisasi kompleks dengan visi dan misi yang berbeda. dari perusahaan, sehingga proses pengaturannya pun akan berbeda pula. Walaupun demikian, dalam pelaksanaannya manajemen pendidikan lebih banyak diilhami dari teori administrasi dan manajemen pada umumnya.
Sebagaimana diungkapkan Fakry Gaffar (2001) "Guna mewujudkan makna manajemen pendidikan secara operasional perlu dipahami fungsi-fungsi pokok manajemen tersebut, yaitu perencanaan, pelaksanaan dan pengawasan". Ketiga fungsi tersebut hanya merupakan bagian dari fungsi manajemen karena masih banyak fungsi lain yang dikemukakan para ahli serta dapat diterapkan dalam berbagai bidang termasuk bidang pendidikan. Tetapi dari sekian banyak fungsi manajemen yang dikemukakan para ahli, ketiga fungsi tersebut merupakan fungsi yang paling mudah dipahami. Perencanaan merupakan kegiatan penting yang harus dilakukan dalam proses manajemen karena tanpa perencanaan tujuan suatu kegiatan akan sulit tercapai serta me-mungkinkan munculnya berbagai hambatan yang sulit ditanggulangi. Perencanaan merupakan proses terstruktur sebagaimana dikemukakan Fakry Gaffar (2001) bahwa "Kegiatan-kegiatan perencanaan dan pelaksanaan perencanaan memerlukan tahapan-tahapan sesuai dengan karakteristik perencanaan yang sedang dikembangkan". Selain proses perencanaan dan pelaksanaan, pengawasan juga penting untuk dilakukan sebagai monitoring terhadap pelaksanaan rencana dan memudahkan penemuan terhadap penyimpangan yang terjadi sehingga mengurangi resiko kegagalan. Proses manajemen perlu diterapkan dalam semua aspek kehidupan termasuk pendidikan. Keberhasilan pendidikan akan sangat menentukan keberhasilan, pembangunan karena tujuan pendidikan adalah mencetak sumber daya manusia berkualitas sebagai 
pelaksana pem-bangunan. Dalam hal ini, Fakry Gaffar (2001) mengemukakan: "Manajemen pendidikan di Indonesia merupakan titik sentral dalam mewujudkan tujuan pembangunan sumber daya manusia. Ber-dasarkan hasil pengamatan para ahli, menunjukkan bahwa manajemen pen-didikan kita masih belum menampakkan kemampuan profesional sebagaimana diharapkan. Kemelut sering terjadi karena ketidak matangan manajemen. Kemelut dalam bidang kurikulum, dalam bidang pengadaan prasarana dan sarana pendidikan, dalam bidang pengangkatan dan dalam bidang kualitas, sebenarnya kontribusi dari manajemen yang belum kuat. Aspek yang menonjol kelemahannya adalah sistem dan faktor manusianya. Sistem pendidikan kita masih terlalu dipengaruhi oleh politik. Karena itu sangat terasa bahwa sistem pendidikan kita tidak responsif terhadap berbagai perkembangan sosial teknologi yang begitu cepat melanda masyarakat. Kurangnya sikap profesional, lemahnya sikap hidup yang rasional dan kemauan untuk berkarya, serta lemahnya disiplin ilmu dalam bekerja menyebabkan produktivitas kerja rendah dan akibatnya produksi sistem juga rendah. Persoalan kualitas sebenarnya persoalan lemahnya manajemen karena orientasi manajemen masih belum pada pembelajaran anak didik. Berbagai hal di atas secara perlahanlahan berkembang menjadi sikap hidup personil dalam manajemen dan bilamana itu tumbuh menjadi budaya manajemen dalam pendidikan Indonesia, pendidikan Indonesia yang berkualitas sulit diwujudkan. Mutu pendidikan yang merupakan bagian dari manajemen pendidikan, akhir-akhir ini muncul menjadi masalah nasional yang dipandang sangat merisaukan. Mutu atau kualitas pendidikan adalah sentral karena pendidikan yang diharapkan adalah pendidikan yang mampu menghasilkan sumber daya manusia berkualitas. Manusia berkualitas tidak mungkin dihasilkan oleh pendidikan yang tidak bermutu. Karena itu pembangunan pendidikan harus diartikan sebagai pembangunan kualitas pendidikan. Ukuran kualitas pendidikan didasarkan atas standar hasil yang ditentukan bersama dan telah menjadi konsensus bersama sesuai dengan level, jenjang dan jenis pendidikan. Kualitas dalam konteks ini merupakan hasil proses yang panjang dan sangat kompleks, karena faktor-faktor yang terlibat di dalamnya juga sangat kompleks. Faktor-faktor itu antara lain: guru, kurikulum, fasilitas pengajaran, manajemen, murid, sumber belajar, teknologi dan evaluasi. Pendidikan yang berkualitas memang harus ditunjang oleh faktor-faktor berkualitas pula. Secara konseptual proses manajemen pendidikan mencakup perencanaan, pengorganisasian, pelaksanaan pembelajaran, pengendalian dan pengevaluasian. Selanjutnya, unsurunsur proses tersebut akan diuraikan berikut ini.

1. Perencanaan

Perencanaan sebagai bagian penting dalam proses manajemen merupakan suatu tahap yang harus dilewati sebelum melangkah ke tahap berikutnya, karena melalui proses ini dapat ditentukan tujuan yang hendak dicapai melalui proses tersebut 
disesuaikan dengan kebutuhan serta fakta-fakta di lapangan. Sebagaimana diungkapkan Maman Ukas (2003) bahwa perencanaan dapat didefinisikan sebagai "suatu proses penggunaan fakta-fakta yang berhubungan dengan dugaan masa yang akan datang yang akan diikuti dengan tindakan perbuatan untuk mencapai tujuan tertentu".

Sehubungan dengan hal tersebut maka pendirian PKBM sebagai suatu wadah pemberdayaan masyarakat memerlukan suatu perencanaan yang matang dengan memperhatikan persyaratan-persyaratan tertentu serta penggunaan strategi yang tepat dalam mewujudkannya. Melalui perencanaan yang baik PKBM diharapkan dapat menjadi suatu wadah pemberdayaan masyarakat yang benar-benar handal sehingga mampu meningkatkan kualitas hidup masyarakat sebagaimana yang diharapkan dan pada akhirnya mampu meningkatkan kualitas sumber daya manuasia secara menyeluruh. Adapun langkah-langkah yang dapat ditempuh dalam suatu proses perencanaan PKBM berdasarkan Balai Pengembangan Kegiatan Belajar (2001) adalah sebagai berikut: (1) Melakukan pendataan umum masalah/kebutuhan dan sumber daya pendukungnya; (2) Menyusun prioritas kebutuhan program masing-masing bidang; (3) Menyusun program kegiatan layanan; dan (4) Menyusun program kerja tahunan PKBM.

2. Pengorganisasian

Pengorganisasian sebagai salah satu fungsi manajemen bertujuan menciptakan hubungan yang baik antar tiap bagian sehingga mampu melahirkan koordinasi yang baik antara atasan dengan bawahan dalam suatu organisasi. Sehubungan dengan hal tersebut Maman Ukas (2003) mengemukakan bahwa "ada tiga langkah yang dapat dilaksanakan: 1) Merancangkan struktur organisasi, 2) Mendefinisikan wewenang, pendelegasian wewenang dan tanggungjawab, dan 3) Menetapkan hubungan kerja". Sejalan dengan tujuan pengorganisasian di atas, berdasarkan Balai Pengembangan kegiatan pembelajaran menjelaskan bahwa tujuan pengoranisasian dalam PKBM adalah: (1) Pendayagunaan sumber daya untuk pelaksanaan program/kegiatan; (2) Pelaksanaan program atau kegiatan; (3) Tenaga kependidikan pada penyelenggaraan PKBM dan pelaksanaan program kegiatan. Adapun kegiatan yang dilakukan dalam proses pengorganisasian PKBM sebagaimana diuraikan Balai Pengembangan Kegiatan Belajar (2001) adalah sebagai: (1) Menyiapkan dan menggerakkan sumber daya yang teridentifikasi; (2) Mengkaji dan menata sumber daya yang akan dimanfaatkan sesuai dengan kebutuhan atau tuntutan program/kegiatan; dan (3)

Menata pelaksanaan program/kegiatan serta menata tenaga kependidikan.

3. Pelaksanaan Pembelajaran

Pada prinsipnya pelaksanaan pem-belajaran di PKBM tidak jauh 
berbeda dengan pelaksanaan pembelajaran pada sistem persekolahan, namun di dalam PKBM kegiatan pembelajaran lebih berorientasi pada kebutuhan masyarakat setempat disesuaikan dengan perkembangan ilmu pengetahuan serta tuntutan pasar, di samping itu warga belajar yang ada di dalam PKBM tidak dibatasi oleh usia sebagaimana dalam pendidikan persekolahan. Adapun kegiatan dalam pelaksanaan PKBM berdasarkan Balai Pengembangan Kegiatan Belajar (2001) adalah: (1) Memotivasi warga belajar, (2) Mengadakan dan atau mengembangkan bahan belajar pokok bagi warga belajar dan bahan pengajaran pokok bagi tutor/narasumber; (3) Melaksanakan proses belajar mengajar; dan (4) Menilai proses dan hasil kegiatan mengajar secara berkala.

4. Pengendalian dan Pengevaluasian

Proses pelaksanaan kegiatan dalam berbagai bidang perlu dikendalikan serta dievaluasi secara berkesinambungan guna memperoleh hasil yang maksimal. Demikian halnya pelaksanaan PKBM sebagai suatu wadah pengembangan sumber daya manusia, karenanya Balai Pengembangan Kegiatan Belajar (2001) menetapkan langkah-langkah: (1) Melaksanakan pemantauan dan pengendalian pelaksanaan program/kegiatan; (2) Mengukur tingkat pencapaian tujuan penyusunan; (3) Menyusun rekomendasi hasil pengukuran dan bahan masukan penyusunan rencana kerja tahunan; dan (4) Menyusun laporan tahunan penyelenggaraan PKBM.

\section{METODE PENELITIAN}

Metode yang digunakan dalam penelitian ini adalah metode deskriptif kualitatif "Metode penelitian kualitatif, merupakan Penelitian yang dilakukan untuk mengetahui nilai variabel atau lebih (independen) tanpa membuat perbandingan, atau menghubungkan antara variabel satu dengan variabel yang lain (Sujiono, 2009 :11). Dengan menggunakan teknik pengumpulan data digunakan oleh peneliti dalam kegiatan penelitian ini adalah sebagai berikut.

a. Observasi

Observasi (observation) atau pengamatan merupakan suatu teknik atau mengumpulkan data dengan jalan meng-adakan pengamatan terhadap kegiatan yang sedang berlangsung. Kegiatan ter-sebut bisa berkaitan dengan cara tutor mengajar, WB belajar, Observasi dapat dilakukan secara partisipatif maupun non partisipatif. Dalam obervasi partisipatif (participatory observation) pengamat ikut serta dalam kegiatan yang sedang ber-langsung sebagai peserta program kegiatan. Dalam observasi non partisipatif (non participatory observation) pengamat tidak ikut dalam kegiatan, dia hanya berperan mengamati kegiatan, tidak ikut dalam kegiatan.

b. Wawancara

Wawancara

(interview) merupakan salah satu bentuk teknik 
pengumpulan data yang banyak digunakan dalam penelitian deskriptif kualitatif, bahkan boleh dikatakan wawancara merupakan teknik pengumpulan data utama. Wawancara dilaksanakan secara lisan dalam pertemuan tatap muka secara individual ataupun kelompok. Menurut Sukmadinata (Metode penelitian, 2005: 112-113) mengatakan bahwa, "wawancara dapat dilakukan dalam beberapa bentuk yaitu wawancara informal, wawancara dengan menggunakan pedoman wawancara dan wawancara terbuka berstandar.

c. Studi Dokumentasi

Studi dokumentasi menurut Sukmadinata (metode penelitian, 2005: 221) "merupakan suatu teknik pengumpulan data dengan menghimpun dan menganalis dokumen-dokumen, baik dokumen tertulis, gambar maupun elektronik" Dokumen-dokumen yang dihimpun dipilih sesuai dengan tujuan dan fokus masalah. Dokumen tersebut diurutkan sesuai dengan sejarah kelahiran, kekuatan dan kesesuaian isinya dengan tujuan pengkajian. Isinya di analisis, dibandingkan, dan dipadang bukan membentuk satu hasil kajian yang sistematis, padu dan utuh. Sedangkan sampel penelitiannya sebanyak 6 orang, yaitu 1 orang tutor PKBM dan 5 orang warga belajar.

\section{HASIL DAN PEMBAHASAN}

Berdasarkan penelitian yang telah dilakukan diperoleh hasil bahwa program Kesetaraan Paket B Setara SMP yang dilaksanakan di PKBM Bina Mandiri Ciageran dilatarbelakangi oleh masih banyaknya warga masyarakat yang putus sekolah dikarenakan jarak yang lumayan jauh untuk menuju ke sekolah formal. Tujuan dari diselenggarakannya program Kesetaraan Paket B Setara SMP tersebut adalah untuk memberikan akses pendidikan bagi masyarakat yang masih putus. Sasaran dari program Kesetaraan Paket B Setara SMP tersebut adalah warga atau msyarakat yang belum mendapatkan pendidikan SMP secara formal.

Peran PKBM sebagai informal leader, menjadi pemimpin di dalam masyarakat sekitarnya. Mereka dipandang memiliki beberapa kelebihan dalam masyarakat baik dari segi pengetahuan, keterampilan maupun sosial ekonominya, memiliki pengaruh cukup kuat bagi masyarakat di sekitarnya. Pengaruh tersebut yang dapat dipergunakan oleh pengelola PKBM Bina Mandiri untuk menggerakkan warga masyarakatnya. Partisipasi pengelola PKBM pada pelaksanaan program Kesetaraan Paket B Setara SMP di PKBM Bina Mandiri diantaranya sebagai pemrakarsa, motivator, tutor, pengelola.

\section{KESIMPULAN}

Peran aktif dari warga belajar pada program Kesetaraan Paket B Setara SMP tidak lepas dari dukungan pihak keluarga dan tokoh masyarakat. Peran PKBM sebagai penggerak, yang memberikan informasi, pengarahan, dukungan dan motivasi pada warga belajar agar mengikuti program tersebut. Beberapa orang sebagai pengelola dan tutor yang 
berhubungan langsung dengan pembelajaran. Peran PKBM tidak berhenti pada hal itu saja, tokoh masyarakat juga berperan dalam membantu menyediakan fasilitas belajar demi kelancaran kegiatan pembelajaran Kesetaraan Paket B Setara SMP.

PKBM sebagai pemrakarsa, memberikan gagasan dan ikut serta dalam rapat bersama pengelola membahas penyelenggaraan program. Sebagai pengelola, memantau bahkan ikut serta membatu tutor melaksanakan pembelajaran. Sebagai tutor, melibatkan warga belajar dalam pembelajaran, seperti pemilihan materi sesuai kebutuhan dan minat warga belajar. Selain itu tutor menggunakan metode dan materi yang variatif agar warga belajar berminat dan terus berpartisipasi dalam program Kesetaraan Paket B. Pengelola PKBM sebagai motivator secara aktif memotivasi warga belajar dalam kegiatan-kegiatan kemasyarakatan maupun di luar itu. Tokoh masyarakat memberikan informasi, pengarahan dan dukungan pada warga belajar. Tokoh masyarakat sebagai fasilitator pembelajaran berperan dalam menyediakan tempat untuk melaksanakan kegiatan pembelajaran.

Saran yang di berikan oleh peneliti untuk Pengelola PKBM adalah Koordinasi antara PKBM dengan tokoh masyarakat lebih ditingkatkan, agar program-program yang akan dilaksanakan mendapat dukungan dari tokoh masyarakat dan dapat disebarluaskan pada anggota masyarakat yang dapat dikenai program tersebut.

Bagi Tokoh Masyarakat: Peran PKBM lebih meningkatkan intensitas waktu dalam memberikan informasi, pengarahan dan dukungan moril bagi masyarakat yang putus sekolah maupun agar mengikuti program Kesetaraan Paket B. Peran PKBM lebih mengembangkan perannya sebagai mediator bagi warga belajar program Kesetaraan Paket B.

\section{DAFTAR PUSTAKA}

Abdurrahman, Mulyono. 1999. Pendidikan Bagi Anak Berkesulitan Belajar. Jakarta: Rineka Cipta.

Abror, Rachman. 1993. Psikologi Pendidikan. Yogyakarta: Tiara Wacana. Albertus Heriyanto, B.

Ahira Anne. (2007). Tokoh Masyarakat. Bandung. Tarsito.

Arikunto, Suharsimi. 2006. Prosedur Penelitian Suatu Pendekatan Praktik. Jakarta: Rineka Cipta.

Azhari. 2002. Pengukuran Hasil Belajar. Jakarta: LAN.

Departemen Pendidikan dan Kebudayaan. 2003. Kurikulum Sekolah Menengah Umum: Landasan, Program dan Pengembangan. Jakarta: Depdikbud.

Effendi, E. Usman dan Juhaya S. Praja. 1985. Pengantar Psikologi. Bandung: Angkasa.

Evans. R.(2008). Pendidikan Non Formal. Jakarta. Grasindo 
Hamalik, Oemar. 1994. Pengembangan Kurikulum dan Pembelajaran: Dasar dan Strategi Pelaksanaannya di Perguruan Tinggi. Jakarta: Trigenda Karya.

Hamijoyo, S. (1988). Model Komunikasi Dua Tahap. Jakarta. Lubuk Agung.

Hasibuan, J. J. dan Moedjiono. 2004. Proses Belajar Mengajar. Bandung: Remaja Rosdakarya.

Kamil, Mustofa. 2009. Pendidikan Nonformal: Pengembangan Melalui Pusat Kegiatan Belajar Mengajar (PKBM) di Indonesia (Sebuah Pembelajaran dari Kominkan di Jepang). Bandung: Alfabeta.

Kamisa. 1997. Kamus Lengkap Bahasa Indonesia. Surabaya: Kartika. Nasution, S. 1982. Metoda Research. Bandung: Jemmars.

Nawawi, Hadari. 2001. Perencanaan Sumber Daya Manusia untuk Organisasi Profit yang Kompetitif. Yogyakarta: Gajah Mada University Press.

Pasaribu, I. L. dan Simandjuntak. 1983. Proses Belajar Mengajar. Bandung: Tarsito.

Purwanto, Heri. 1994. Pengantar Statistik Keperawatan. Jakarta: EGC.

Rahayu, Linda. 2009. Meningkatkan Minat Membaca Pada Anak yang
Mengalami Kesulitan Membaca Melalui Permainan Konstruktif. Skripsi. Fakultas Psikologi, Universitas Muhammadiyah Malang.

Rakhmat, Jalaluddin. 1995. Metode Penelitian Komunikasi. Bandung: Remadja Karya.

Republik Indonesia. 2005. Peraturan Pemerintah Republik Indonesia Nomor 19 Tahun 2005 Tentang Standar Nasional Pendidikan.

Sandjaja. 2006. Panduan Penelitian. Jakarta: Prestasi Pustaka.

Sardiman. 1985. Didaktif Asas-asas Mengajar. Bandung: Jemmars.

Setiadi, Hari. 2000. Studi Perbandingan Kemampuan Warga Belajar Paket B dengan Kemampuan Siswa SLTP Menggunakan Analisis Teori Tes Modern (Item Response Theory). Jurnal Pendidikan dan Kebudayaan. Vol. 6, No. 23, 2000. Hlm. 26-39.

Sevilla, Consuelo G. 1993. Pengantar Metode Penelitian. Jakarta: Penerbit Universitas Indonesia (UI-Press).

Singarimbun, Masri. 1989. Metode Penelitian Survai. Jakarta: Pustaka LP3ES. Slameto. 1995. Belajar dan Faktor-Faktor yang Mempengaruhinya. Jakarta: Rineka Cipta. 
Sudjana, Nana. 1991. Penilaian Hasil Belajar Mengajar. Bandung: Remaja Rosdakarya.

Sudjoko, et. al. 2011. Pendidikan Lingkungan Hidup. Jakarta: Universitas Terbuka.

Sujiono. (2009). Metode Penelitian. Jakarta. Grasindo.

Sugiyono. 2010. Statistika untuk Penelitian. Bandung: Alfabeta.

Sukmadinata. 2006. Metode Penelitian Pendidikan. Bandung: Rosdakarya. Sukirman. 2007. Matematika. Jakarta: Universitas Terbuka.

Sutarno. N. S. 2006. Perpustakaan dan Masyarakat. Jakarta: Sagung Seto.

Sutini. 2010. Upaya Meningkatkan Minat Baca Siswa Kelas III Sekolah Dasar.
Jurnal Kependidikan Interaksi. Tahun 5, No. 5 Juni 2010, 56-64.

Syah, Muhibbin. 2004. Psikologi Pendidikan dengan Pendekatan Baru. Bandung: Remaja Rosdakarya.

Tarigan, Henry Guntur. 1979. Membaca Sebagai Suatu Keterampilan Berbahasa. Bandung: Angkasa.

Tilaar. H.A.R. (2009:287). Manajemen Pendidikan. Bandung. Remaja Rosda Karya.

Warsito, Hermawan. 1992. Pengantar Metodologi Penelitian. Jakarta: Gramedia Pustaka Utama.

Winkel, W. S. 1989. Psikologi Pengajaran. Jakarta: Gramedia. 